\title{
IS SMARTPHONE ADDICTION IN THE YOUNGER POPULATION A PUBLIC HEALTH PROBLEM?
}

\section{Sofija Loleska ${ }^{1}$ and Nada Pop-Jordanova ${ }^{2}$}

${ }^{1} \mathrm{PhD}$ Student at the Faculty of Medicine, Ss. Cyril and Methodius University, Skopje, North Macedonia

${ }^{2}$ Macedonian Academy of Sciences and Arts

Corresponding author: Nada Pop-Jordanova, Bul Krste Misirkov br. 2, P.O.Box 428, 1000 Skopje, RN Macedonia, e-mail: popjordanova.nadica@gmail.com

\section{ABSTRACT}

Problematic smartphone use and or addiction is defined as a form of behaviour characterized by the compulsive use of a smartphone that results in various forms of physical, psychological, or social harm. Global popularity in the area of the use of smartphones has raised concerns about the negative effects associated with problematic smartphone use, especially in the younger population.

Having no consensual definition of smartphone addiction (SA), this behavioural addiction is based on the classic addiction symptomology that was included in DSM-5 criteria for compulsive gambling and substance abuse (APA 2013)

This article provides a review of current research related to SA. Articles were found in the PUBMED database using related key words. Statistics confirm the exponential rise of this problem globally, especially in children and adolescents. Therefore, one must make this a high priority among public health issues.

Keywords: smartphone addition, health, children, adolescent

\section{INTRODUCTION}

Since the introduction of the first cellular phone in 1973 (Motorola) and the iPhone in 2007(Apple), the usage of mobile phones has become an accepted part of our daily lives. From calendars and reminders, to emails and instantaneous access to encyclopaedias in different fields, smartphones give us total control, right at our fingertips. The easy portability allows the smartphone to become the preferred device for accessing the internet and other telecommunication services, social networks, etc.
In previous research, we noted that mobile phones are currently used in medicine as a tool for assessment and for the treatment of many disorders $[1,2,3]$. However, the fact is that mobile phones today are overused and can be the cause of addiction. The World Health Organization has now raised awareness about the potential health implications of excessive mobile phone use, and some researchers have even suggested a possible new form of behavioural addiction.

Currently, there is no consensus on the definition of smartphone addiction (SA). Therefore, 
the term "problematic smartphone use" is more frequently applied, which describes a recurrent failure to control the addictive behaviour that results in functional impairment or distress. This failure meets the criteria for behavioural addiction, as proposed by Kardefelt-Winther et al. (2017) [4]. The context in which the term SA is used could be attributed to the frequency of usage, a direct correlation to depression and/or stress, the extent of withdrawal symptoms as a result of reduced usage, and potential similarities to drug-addiction and alcoholism.

However, this behavioural addiction is based on the classic addiction symptomology that was included in DSM-5 criteria for compulsive gambling and substance abuse (APA 2013) [5].

Thus, problematic smartphone use is defined as a form of behaviour, which is characterized by the compulsive use of the device, resulting in various forms of physical, psychological, or social harm. The global popularity of smartphones has raised concerns about its negative effects associated with problematic smartphone use, especially among the younger population.

The aim of this article is to give a review of published data for SA cited in PubMed over the last few decades. Using this methodology, over 300 related articles were analysed. As key words for this investigation we used: smartphone addiction, children, adolescents, health effects.

\section{RESULTS AND DISCUSSION}

As mentioned above, over 300 published articles found in the PubMed database are analysed. Some interesting data will be presented in the following text.

\section{EPIDEMIOLOGY}

Every human being, but especially children and adolescents, seek to discover, explore, and investigate the potential of smartphones. They do this, in most cases, autonomously. In our previous studies we found that, in Skopje, $98 \%$ of school children regularly used some type of mobile phone. In addition, we confirmed some hypersensitive reactions, as well as an influence on mental activity [6-10]. However, this overuse can lead children to experience age-inappropriate situations. Lack of maturity and skills to manage inappropriate content have even led some of them to experience psychological, physical discomfort or specific behaviours, such as nomophobia.

Nomophobia is a neologism, meaning the fear of not having your phone with you (no-mobile-phone-phobia). During the recent Covid 19 pandemic, this addiction to mobile phones has increased. Statistics have confirmed a $39 \%$ increase in the number of hours people spent on their smartphones in 2020, yet in younger people this percentage is much higher: $68 \%$ of people aged 18-34 spend more than one hour with their smartphones. According to smartphone addiction statistics from 2021, more than half of American smartphone users claim that they have increased their screen time by one hour, due to the coronavirus-induced lockdowns. In this context, Brazilians are placed at first place on mobile phone use, second place is the Chinese, and Americans are in third place. It is interesting that $71 \%$ of people usually sleep with or next to their mobile phone. Actually, cell phone addiction studies show that smartphone use is more dangerous on the road than alcohol abuse [11].

Almost all children (96.6\%) have regular contact with mobile devices and approximately one in ten have already used the internet before age one. Reports show that generally $47 \%$ of parents think that their children are addicted to their smartphones, in Japan $61 \%$ of parents feel their kids have acquired some sort of technology addiction, while this percentage for US parents is $59 \%$. By contrast, $41 \%$ of teens feel overwhelmed by the number of notifications they receive daily, while $33 \%$ of teens spend more time socializing with close friends online, rather than face-to-face.

Smartphone addiction statistics we presented are not just numbers. They represent actual human beings and you probably recognized yourself in some of these statistics.

\section{HEALTH CONSEQUENCES}

Addiction can appear as a habit in which repetitive behaviour is involved, but it is also a more complex activity which involves physiological responses, such as withdrawal symptoms. 
In terms of biological perspectives, habits are related to the cortico-striatal-thalamic circuitry and allow the behaviour to be engaged without involving the prefrontal cognitive circuitry. Still, if habitual behaviour begins to lead to unfavourable results, prefrontal executive processing can impose correction or stop the behaviour. However, addiction is characterized by an inability to cognitively regulate behaviour, while a habit is much more based on choice [12-16]. Thus, even when presented with negative consequences, addictive behaviours will continue. Figure 1 shows the difference between habitual and addictive smartphone behaviour. the irritability and malaise associated with abstinence. In this context, cell phone addiction happened to be one of the greatest addictions of the current century.

Based on the diagnostic criteria of the DSM-5, the following manifestations for SA are noted:

Problematic and conscious use in dangerous situations or prohibited contexts with social and familial conflicts and confrontations, as well as a loss of interest in other activities. A continuation of the behaviour is observed despite the negative effects or the personal malaise caused.

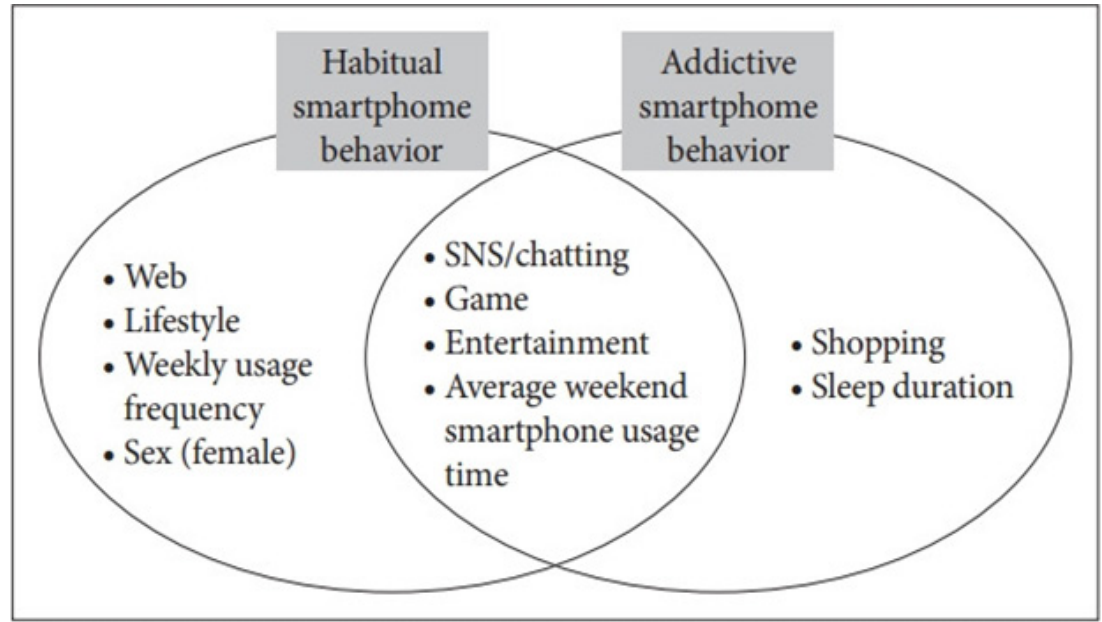

Fig. 1. Predictors for habitual versus addictive behaviour [Front Psychol. 2021; 12: 670223].

Prior to the arrival of the cell phone, abundant research had been conducted on behavioural addictions to video games, exercise, online sex, food, shopping, work, and the internet. Indeed, for several authors, a large number of behaviours are potentially addictive if there is a concurrence of negative consequences and physical and psychological reinforcements in a specific context [17-20].

In general, Brown RIF.[17] and Griffiths MD. $[16,18]$ noted that addiction entails abuse without control, alterations in mood, tolerance, abstinence, and personal harm or environmental conflicts, as well as a tendency to relapse.

Cía AH.[19] highlights the automatism by which these behaviours lead to uncontrollable use, in addition to feelings of intense desire or irresistible need, loss of control, inattention to usual activities, the focalization of interests on the behaviour or activity of interest, the persistence of the behaviour despite its negative effects, and
Harm, repeated physical, mental, social, work, or familial interruptions, preferring the cell phone to personal contact; frequent and constant consultations in brief periods with insomnia and sleep disturbances.

Excessive use, urgency, abstinence, tolerance, dependence, difficulty controlling, craving, increasing use to achieve satisfaction or relaxation or to counteract a dysphoric mood, the need to be connected, feelings of irritability or of being lost if separated from the phone or of sending and viewing messages with feelings of unease when unable to use it.

Anxiety and loneliness when unable to send a message or receive an immediate response; stress and changes in mood due to the need to respond immediately to messages.

The problematic use of cell phones, as mentioned before, is more frequent in among the younger population, particularly among adolescents. The greatest indices of problematic 
use or addiction are found when the first phone is obtained at an age younger than 13 years. (Sahin et al. 2013) [21]. Boys showed a higher tendency to use cell phones in risky situations than girls (Billieux J, et al. 2008) [22]. Concerning social status, it was confirmed that youngsters from families with higher cultural and economic status have a higher level of dependence, which could be the consequence of the greater isolation and loneliness they feel. It appears that greater cell phone dependence exists in East Asian countries, such as Korea (.15\%), 11,15\% which can be explained by their sizeable cell phone offerings and high technological penetration among the youngest strata (Shin LY, 2014) [23].

The "Big Five Personality Traits," also known as the FFM, has been used in research on cell phone use and personality. This inventory explores the five dimensions of personality: extraversion, openness to experience or change, conscientiousness, agreeableness, and neuroticism or emotional instability. Takao M. (2014) [24], showed that in females, the FFM confirmed extraversion, neuroticism, and low openness to experience, while Giota and Kleftaras (2013) [25] observed that SA is related to neuroticism and agreeableness as well as to depression, particularly in females. In many studies, anxiety, depression, and stress are observed, as well as problems with sleep and loneliness related to cell phone overuse [26, 27].

Having statistics for China, where internet users on mobile phones have climbed to 847 million, accounting for $99.1 \%$ of the overall network users by 2019, interesting research has been performed which aims to prove the health issues related to mobile phone addiction and occupational burnout of novice nurses [28]. Novice nurses are in the transition from student to com- petent registered nurses, and they undertake the important task of caring for patients. Burnout is a psychological syndrome and identified by three different factors including emotional exhaustion, depersonalization, and personal accomplishment (Maslach et al., 2016)[29]. It occurs when employees work at high-stress jobs with a heavy workload and long working hours (Boamah et al., 2016)[27]. Studies on the health issues related to mobile phone addiction and the occupational burnout of novice nurses may provoke further investigation into the continuing concerns about patient safety.

The findings of Alavi SS. et al., (2020) [30] revealed a strong association between some psychiatric disorders and mobile phone addiction. These include depression, anxiety, bipolar, dependent personality disorder, compulsive personality disorder, and somatization. Also, it was found that depression, anxiety, and bipolar disorders can significantly predict addiction to smart phones in college students. Adolescent girls appeared to use smartphones excessively. In sum, Alavi SS. et al. assess that the relationship between smartphone addiction and mental disorders in students is considerable.

Generally, the capacity to be alone is important for SA. Fig. 2 proposes a model of interdependence between the capacity to be alone and SA. As is known, this capacity is related to psychological distress and rumination which could be in different degrees.

There has been a proliferation in studies examining the association between digital media use in young people and various aspects of well-being, including neurocognitive development in youngsters, and anxiety and depression in children, teenagers, and young adults. Additionally, its problematic use can affect various fac-

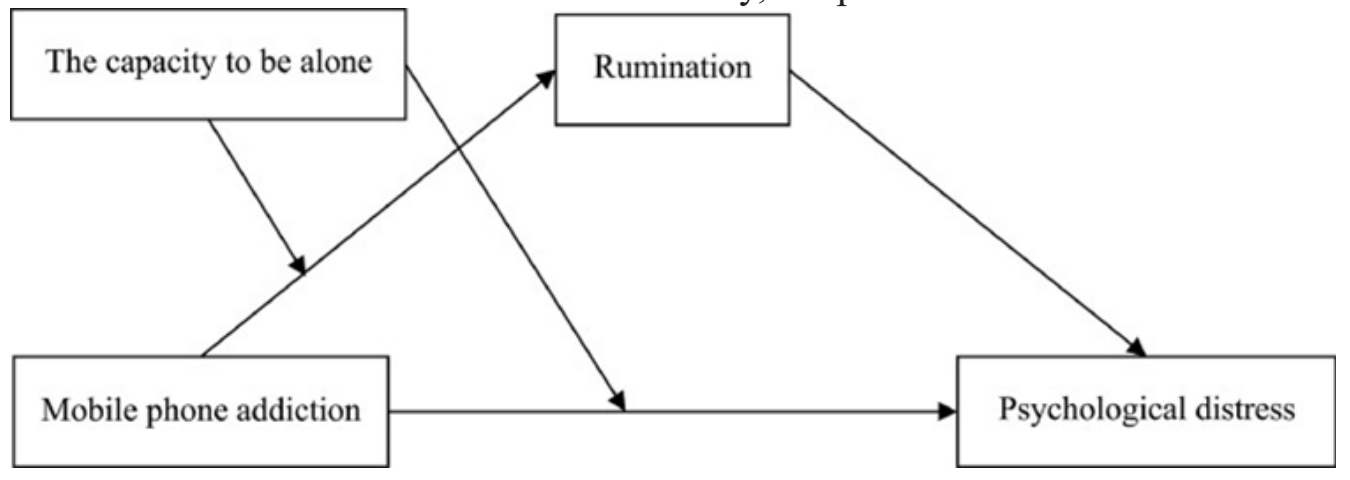

Fig. 2. The capacity to be alone as a moderator to reveal when direct and indirect relations between mobile phone addiction and adolescents' psychological distress are stronger or weaker [Shuai-Lei Lian et al. 2020] 
tors of our daily life, causing, for instance, a lack of practice of physical activity (Zagalaz-Sánchez et al, 2019) [31].

During adolescence, numerous biological, psychological, and social transitions take place, which determine a young person's development and future. These transitions allow adolescents to develop skills in order to achieve greater autonomy, build relationships with peers, develop a positive body image, and find one's identity. However, they are also accompanied by an increased willingness to take risks during a time when the cognitive functions of the brain (e.g. to regulate emotions) are not yet fully developed.

In this context, some studies confirm the relationship between smartphone dependency and aggression among middle school students (Cha, 2018) [32]. Thus, ego-resilience (personal), parenting behaviour (family), and peer attachment (society) were used as variables to understand their interactions with both the internal and external environments from biological, psychological, and social perspectives. Ego-resilience controlled the impact of smartphone dependency on aggression, while smartphone dependency mediated this relationship with aggression. These findings suggest that the development of 'ego-resilience' is important for reducing the side effects of smartphone overuse among both adolescents and young adults. It is thus necessary to provide education, counselling, and various programs for adolescents who are exposed to smartphones in order to control their aggressive behaviours and to help them develop social and communication skills.(Youn-Joo Um et al., 2019) [33].

Sleep deficit, anxiety, stress, and depression are all associated with mobile phone addiction. Two authors, De-Sola Gutiérrez and Matar Boumosleh $[34,35]$ investigated whether anxiety and depression independently contributed to smartphone addiction. Their cross-sectional study proposed that depression and anxiety were also a positive predictor of smartphone addiction. Additionally, they revealed that depression scores were a more powerful predictor as compared to anxiety. De-Sola Gutiérrez et al. (2016) highlighted that problematic cell phone use had been associated with sleep deficit, depression, anxiety, and stress.

It is well known that hypertension, or high blood pressure, is a major public health issue, also as one of the primary risk factors for cardiovascular diseases, including cerebrovascular stroke and atherosclerosis. Zou Y. et al. 2019 [36] investigated and confirmed the risk factors associated with hypertension in Chinese adolescents, aged $12-15$ years, especially the relationship with smartphone addiction.

Many findings (our own as well) affirm that cell phones are quite popular with the public, and they have significant potential for therapeutic use in the healthcare field. Cell phone technology, has been used to manage computer stress, to reduce examination anxiety, to counter battlefield stress, to enhance emotional self-awareness, to promote socially supportive behaviour, to regulate mood status, stress, and coping - to access alcohol easily, behaviours, to monitor mood states and coordinate the activities of surgical wards. Cell phones have also been advocated for use the healthcare environment to facilitate patient reminders about appointments, enable disease monitoring and management, and provide patient education (Sansone R. 2013) [37]. Understanding the potential psychosocial benefits and limitations of this novel technology and their relationships to overall physical and mental health is important in both psychiatric and primary care settings [38].

Learning burnout is a passive mental state recognised especially among medical students. It is a common phenomenon that can cause many negative outcomes, such as mental disorders and even suicide; its causes are complex. In a study by Zhang CH. et al. (2021) [39] alexithymia (as an especial characteristic of personality) was found to be a positive prediction for learning burnout, and this relationship is partially mediated by mobile phone addiction. Macnow T. (2021) on the other side, indicated that screen time could influence recovery from concussion [40].

Finally, the practice of phubbing has become an emerging phenomenon of worldwide interest to researchers. This behaviour is generally considered inappropriate and is called "phubbing". Phubbing is the act of snubbing someone in a social setting by looking at one's phone instead of paying attention to the other person. The article [41] provide an overview of research studies on phubbing through a review of the current literature. The results of the study show the distribution of published articles on phubbing by year, and they detail the type of study and the methodological approach and, finally, the research journals that have published articles on phubbing. The results of this review 
as well as the study [42] are expected to stimulate and guide future research in this field.

\section{CONCLUSION}

All aforementioned studies confirm that adolescent mental health and physical health is associated with cell phone addiction. But we cannot say with $100 \%$ accuracy that mobile phones are the sole cause of poor mental or physiological health issues in adolescents. Parents and teachers, however, together with all those included in the environment of the developing youth should be aware of the health consequences of overuse and or addiction to mobile phones and to work on prevention. It is necessary to provide education, counselling, and various programs for adolescents who are exposed to smartphones in order to control their aggressive behaviours and to help them develop social and communication skills.

\section{REFERENCES}

1. Loleski M, Loleska S, Pop-Jordanova N. (2017) MOBILE APPLICATION "NEUROGAME" FOR ASSESSMENT THE ATTENTION, FOCUS AND CONCENTRATION, CONTRIBUTIONS. Sec. of Med. Sci., XXXVIII 3: 55-62.

2. Pop-Jordanova N, Loleski M, Loleska S. (2017) THE USE OF SMARTPHONE IN MEDICAL PRACTICE, CONTRIBUTIONS. Sec. of Med. Sci., XXXVIII 3: 9-17.

3. Pop-Jordanova N, Loleska S, Loleski M. (2018) ORIGINALLY ADAPTED MOBILE APPLICATION USED FOR NEUROPSYCHIATRIC PATIENTS, CONTRIBUTIONS. Sec. of Med. Sci., XXXIX 1: 75-81.

4. Kardefelt-Winther D, Heeren A, Schimmenti A, van Rooij A, Maurage P, Carras M, Edman J, Blaszczynski A, Khazaal Y, Billieux J. (2017) How can we conceptualize behavioural addiction without pathologizing common behaviours? Addiction. Oct;112(10): 1709-1715.

5. American Psychiatric Association (APA) (2013) DSM-V Diagnostic and Statistical Manual of Mental Disorders. 5th Edition, American Psychiatric Association, Washington, DC.

6. Pop-Jordanova N. (2006) Мобилните телефони и здравјето, Образовни рефлекси; 3: 76-78.

7. Pop-Jordanova N., Pop-Jordanov J. On estimating mental consequences of mobile phone ex- posure, Joint WG3 meeting, COST Action BM 0704 ,Emerging EMF Technologies and Health Risk Management “, Lisbon, November 2010: $1-11$.

8. Pop-Jordanov J., Pop-Jordanova N. (2011) Mobile phones, E E G and Mental Activity, WebmedCentral BRAIN [electronic source], published on: 30.01.2011, article (URL): https:// www.webmedcentral.com/wmcpdf/ispeisticle WMC001370.pdf ; 2 (1): WMC001493 (1-7).

9. Pop-Jordanova N., Pop-Jordanova S. (2012) Health symptoms caused by electromagnetic radiation, Physioacta; 6 (2): 33-45.

10. Pop-Jordanova N., Loleska S. (2015) Some negative effects of mobile phone's use, International Journal of Scientific Engineering and Applied Science (IJSEAS); 2 (6): 2395-3470.

11. Ministry of Science and ICT NIA 2019 The survey on smartphone overdenpendence. NIA. 2020: p. 8-9.

12. Billieux J, Maurage P, Lopez-Fernandez O, Kuss DJ, Griffiths MD. (2015) Can disordered mobile phone use be considered a behavioural addiction? An update on current evidence and a comprehensive model for Future research. Curr Addict Rep.; 2: 156-162.

13. Van Deursen AJ, Bolle CL, Hegner SM, Kommers PA. (2015) Modeling habitual and addictive smartphone behavior: the role of smartphone usage types, emotional intelligence, social stress, self-regulation, age, and gender. Comput Human Behav.; 45: 411-420.

14. Oulasvirta A, Rattenbury T, Ma L, Raita E. (2012) Habits make smartphone use more pervasive. Pers Ubiquit Comput; 16: 105-114.

15. Everitt BJ, Robbins TW. (2005) Neural systems of reinforcement for drug addiction: from actions to habits to compulsion. Nat Neurosci.; 8: 1481-1489.

16. Griffiths MD. (2005) A 'components' model of addiction within a biopsychosocial framework. J Subst Use; 10: 191-7.

17. Brown RIF. (1993) Some contributions of the study of gambling to the study of other addictions. In: Eadington WR, Cornelius JA, editors. Gambling Behavior and Problem Gambling. Reno, NV: University of Nevada Press: 341-72.

18. Griffiths MD. (1996) Nicotine, tobacco and addiction. Nature; 384: 18.

19. Cía AH. (2013) Las adicciones no relacionadas a sustancias (DSM-5, APA, 2013): Un primer paso hacia la inclusión de las Adicciones Conductuales en las clasificaciones categoriales vigentes. Revista de Neuropsiquiatría; 76: 210-7.

20. De-Sola Gutiérrez J, Rodríguez de Fonseca F, Rubio G. (2016) Cell-phone addiction: a review. Front Psychiatry; 7: 175. 
21. Sahin S, Ozdemir K, Unsal A, Temiz N. (2013) Evaluation of mobile phone addiction level and sleep quality in university students. Pak J Med Sci; 29:913-8.10.12669/pjms.294.3686

22. Billieux J, Van Der Linden M, Rochat L. (2008) The role of impulsivity in actual and problematic use of the mobile phone. Appl Cogn Psychol; 22: 1195-210.10.1002/acp.1429

23. Shin LY. (2014) A comparative study of mobile internet usage between the US and Korea. J Eur Psychol Stud; 5: 46-55.

24. Takao M. (2014) Problematic mobile phone use and big-five personality domains. Indian J Community Med; 39: 111-3.

25. Giota K, Kleftaras G. (2013) The role of personality and depression in problematic use of social networking sites in Greece. Cyberpsychology; 7:6.10.5817/CP2013-3-6

26. Boumosleh JM, Jaalouk D. (2017) Depression, anxiety, and smartphone addiction in university students- a cross-sectional study. PLos ONE;12(8): e0182239.

27. Boamah, S. A., Read, E.A., \& Spence Laschinger, H. K. (2016). Factors influencing new graduate nurse burnout development, job satisfaction and patient care quality: A time-lagged study. Journal of Advanced Nursing, 73(5): 1182-1195.

28. Huan Ma, Ji-Qun He, Jin-Mei Zou, and Ying Zhong (2021) Mobile phone addiction and its association with burnout in Chinese novice nurses: A cross-sectional survey. Nurs Open. Mar; 8(2): 688-694.

29. Maslach, C. \& Leiter, M. P. (2016). Understanding the burnout experience: Recent research and its implications for psychiatry. World Psychiatry, 15(2): 103-111.

30. Alavi SS, Maryam Ghanizadeh, Malihe Farahani, Fereshteh Jannatifard, Sudeh Esmaili Alamuti, and Mohammad Reza Mohammadi (2020) Addictive Use of Smartphones and Mental Disorders in University Students. Iran J Psychiatry.; 15(2): 96-104.

31. Zagalaz-Sánchez ML, Javier Cachón-Zagalaz, María Sánchez-Zafra, and Amador Lara-Sánchez. (2019) Mini Review of the Use of the Mobile Phone and Its Repercussion in the Deficit of Physical Activity. Front Psychol.; 10: 1307.

32. Cha S-S, Seo B-K. (2018) Smartphone use and smartphone addiction in middle school students in Korea: prevalence, social networking service, and game use. Health Psychology Open.; 2018: $1-5$.

33. Youn-Joo Um, Yun-Jung Choi, and So Yeon Yoo (2019) Relationships Between Smartphone Dependency and Aggression Among Middle School Students: Mediating and Moderating Effects of Ego-Resilience, Parenting Behaviour, and Peer Attachment. Int J Environ Res Public Health.; 16(19): 3534.

34. José De-Sola Gutiérrez, Fernando Rodríguez de Fonseca and Gabriel Rubio (2016) CellPhone Addiction: A Review. Front. Psychiatry, 24 October 2016 | https://doi.org/10.3389/fpsyt.2016.00175

35. Matar Boumosleh J, Jaalouk D (2017) Depression, anxiety, and smartphone addiction in university students- A cross sectional study. PLoS ONE 12(8): e0182239. PLoS ONE 12(8): e0182239.

36. Zou Y, Ning Xia, Yunqing Zou, Zhen Chen, and Yufeng Wen (2019) Smartphone addiction may be associated with adolescent hypertension: a cross-sectional study among junior school students in China. BMC Pediatr.; 19: 310.

37. Sansone RA, Sansone LA. (2013) Cell phones: the psychosocial risks. Innov Clin Neurosci. Jan;10(1): 33-7. PMID: 23439568; PMCID: PMC3579483.

38. Randy A. Sansone, and Lori A. Sansone. )(2013) Cell Phones - The Psychosocial Risks, Innov Clin Neurosci. ; 10(1): 33-37.

39. Zhang CH, Li G, Fan ZY, Tang XJ, Zhang F. (2021) Mobile Phone Addiction Mediates the Relationship Between Alexithymia and Learning Burnout in Chinese Medical Students: A Structural Equation Model Analysis. Psychol Res Behav Manag. Apr 12; 14: 455-465.

40. Macnow T et al, (2021) Effect of Screen Time on Recovery From Concussion, JAMA Pediatrics . DOI: 10.1001/jamapediatrics.2021.2782

41. Capilla Garrido E, Issa T, Gutiérrez Esteban P, Cubo Delgado S. (2021) A descriptive literature review of phubbing behaviors. Heliyon. May 18; 7(5): e07037.

42. Shoukat S. (2019). Cell phone addiction and psychological and physiological health in adolescents. EXCLI journal, 18, 47-50. 


\title{
Резиме
}

\section{ДАЛИ ЗАВИСНОСТА ОД ПАМЕТНИ ТЕЛЕФОНИ КАЈ ПОМЛАДОТО НАСЕЛЕНИЕ} Е ПРОБЛЕМ ЗА ЈАВНОТО ЗДРАВЈЕ?

\author{
Софија Лолеска ${ }^{1}$ и Нада Поп-Јорданова ${ }^{2}$ \\ ${ }^{1}$ Докторанд на Медицинскиот факултет, Св. Кирил и Методиј, Скопје, Северна Македонија \\ ${ }^{2}$ Македонска академија на науките и уметностите
}

Проблематичната употреба/зависност од паметни телефони се дефинира како форма на однесување што се карактеризира со присилна употреба на уредот, кој резултира со различни форми на физичка, психолошка или социјална штета. Оваа глобална популарност ја зголеми загриженоста за нејзините негативни ефекти поврзани со проблематичната употреба на паметни телефони, особено кај младата популација.

Немајќи консензуална дефиниција за СА, оваа зависност во однесувањето се базира на класичната симптоматологија за зависност, која беше вклучена во критериумите ДСМ-5 за компулсивно коцкање и злоупотреба на супстанции (АПА 2013).

Написот дава преглед на истражувањата поврзани со СА. Написите се наоѓаат во базните податоци PUBMED, користејќ́ релевантни клучни зборови. Статистиката потврдува експоненцијален пораст на овој проблем во глобалниот свет и, особено, кај децата и кај адолесцентите, давајќи му висок приоритет како прашање од интерес за јавното здравје.

Клучни зборови: зависност од мобилни телефони, здравје, деца, адолесценти 